\title{
THE POSITION OF WORKERS IN THE ON-DEMAND ECONOMY: THE NEED FOR INCREASED PROTECTION
}

\begin{abstract}
In this paper, the author focuses her attention on the situation of workers in the on-demand economy. Firstly, she deals with problems of terminological nature. Secondly, she presents the justification for protection for some categories of workers. Thirdly, the analysis of the status of ondemand workers is conducted from different points of view: proposal to introduce the intermediate category between employee and independent contractor, proposal to introduce an employment relationship as the default classification, a functional concept of the employer, the judgment of Employment Tribunal (London) in Aslam and Farrar and others, and A European agenda for the collaborative economy. Finally, the author considers the usefulness (in the on-demand economy) of some of the instruments introduced by the General Data Protection Regulation of 27 April 2016.
\end{abstract}

Słowa kluczowe: rynek umów krótkoterminowych, gospodarka na żądanie, niepewność pracy, status pracowników na żądanie, ogólne rozporządzenie o ochronie danych z dnia 27 kwietnia 2016 r.

Key words: gig economy, on-demand economy, "cybertariat", precariousness of work, the status of ondemand workers, the General Data Protection Regulation of 27 April 2016

\section{Introduction}

Technology is reorganising the future of work. According to expert estimations, by 2020 contingent workers will constitute almost half of all workers in the US, of whom 11 percent will be working for platforms. Work on internet platforms has been growing rapidly in the last few years. In 2015, gross revenue from collaborative platforms in the EU was assessed $€ 28$ billion, which was almost two times more than a year earlier. ${ }^{1}$ In the beginning of 2016, over fourteen million people worked in the "gig economy". ${ }^{2}$ McKinsey

1 M. Schmid-Drüner, The situation of workers in the collaborative economy, European Parliament 2016, p. 1; see the cited literature.

2 M.A. Cherry, Beyond misclassification: the digital transformation of work, Comparative Labor Law \& Policy Journal 2016, 37, 3, p. 577-578; A. Aloisi, Commoditized workers: Case study research on labor law issues arising from a set of "on-demand/gig economy" platforms, Comparative Labor Law \& Policy Journal 2016, 37, 3, p. 659. 
Global Institute predicts that on-demand economy business models will increase global GDP by $\$ 2.7$ trillion by $2025 .{ }^{3}$ Regrettably, today's labour and employment laws do not meet the needs of the new reality.

This paper will proceed as follows: terminological problems are signalled before the justification for protection for some categories of workers is presented. This is followed by the analysis of the status of on-demand workers conducted from different points of view: proposal to introduce the intermediate category between employee and independent contractor, proposal to introduce an employment relationship as the default classification, a functional concept of the employer, the judgment of Employment Tribunal (London) in Aslam and Farrar and others v Uber BV, Uber London Ltd and Uber Britannia Ltd (2202550/2015), and Communication from the Commission to the European Parliament, the Council, the European Economic and Social Committee and the Committee of the Regions. A European agenda for the collaborative economy. Then, some problems linked to the data protection in the on-demand economy are outlined. Here I focus on the General Data Protection Regulation of 27 April 2016 which establishes a data subject's right to have personal data concerning him or her rectified and a "right to be forgotten". I also comment on profiling. The paper ends by drawing some conclusions.

\section{Terminological problems}

There is a difference between the sharing economy and the on-demand economy. For example, renting out a private residence or a single room through Airbnb platform entails only the tenant's use of the property (sharing economy), while the functioning of Uber platform needs work performed by drivers (on-demand economy). The former is referring to consumers in some way sharing their property with users or renters, ${ }^{5}$ that is why the latter has a greater importance from the point of view of labour law (it requires carrying out the human work).

Some of the authors point out that on-demand economy involves "physical services", e.g. cleaning, plumbing, childcare, driving passengers around, the execution of which is channeled through apps managed by platforms. Therefore, it should be distinguished from "crowdwork" - the term which is referred to working activities that imply completing a series of tasks through online platforms. "Virtual services", e.g. accounting or

3 J. Manyika, S. Lund, K. Robinson, J. Valentino, R. Dobbs, A labor market that works: connecting talent with opportunity in the digital age, 2015; http://www.mckinsey.com/global-themes/employmentand-growth/connecting-talent-with-opportunity-in-the-digital-age (accessed: 14.09.2017).

4 Otherwise E.E. McCabe. She has classified e.g. Uber within the "sharing economy", E.E. McCabe, Not like the others: Applying the fair labor standards act to the sharing economy, Kansas Law Review 2016, 65, 1 , passim.

5 B. Gomes, Le crowdworking: essai sur la qualification du travail par intermédiation numérique, Revue de Droit du Travail 2016, 7-8, p. 467; D.E. Sanders, P. Pattison, Worker characterization in a gig economy viewed through an Uber centric lens, Southern Law Journal 2016, 26, 2, p. 297. 
translation tasks are transmitted via internet and can be performed anywhere without territorial limitations. At the beginning of 2015 there were about 2,300 crowdsourcing platforms in the world. ${ }^{6}$ The also so-called "clickwork" is a form of task subdivision that, on the one hand, centres on low-skilled tasks, e.g. identifying spelling errors, hunting for email addresses, text transcription, data entry or image tagging, dismantled into microtasks, and - on the other hand - engages more complex tasks, e.g. review writing, social media work, sales and marketing, cloud computing work, IT networking and security, administrative support, design, animation. ${ }^{7}$ However, sometimes in the literature the term "work crowdsourced" is seen as having two aspects: physical work to be undertaken in the real (offline) world, and digital work delivered in the virtual (online) world. ${ }^{8}$ Moreover, according to some authors, the notions of "work-on-demand via app" and "crowdwork" make up the broader concept of the "gig-economy". ${ }^{9}$ Other scientists represent different points of view, namely that expressions like "on-demand economy" and "gig-economy" are interchangeable, and are used as a general umbrella in order to be broadly understood. ${ }^{10}$

Leaving aside classification problems, it should be explicitly stated that the aim of employment and labour law is to distinguish the genuinely self-employed from those who need protection, and bring the latter within its protective realm. ${ }^{11}$ I refer here to my article (co-authored with A. Todolí Signes) entitled: The need for a platform-specific employment contract in the Uber economy, published in Gdańsko-€ódzkie Roczniki Prawa Pracy i Prawa Socjalnego 2016. In the above-mentioned paper, we demonstrate that employees who perform work offline through a specific online platform should be protected under labour law and we propose the creation of a special employment contract.

6 W. Däubler, T. Klebe, Crowdwork: datore di lavoro in fuga?, Giornale di diritto del lavoro e di relazioni industriali fondato da Gino Giugni, 2016, 131, 3, p. 474-475; V. De Stefano, The rise of the "justin-time workforce": On-demand work, crowdwork, and labor protection in the "gig economy", Comparative Labor Law \& Policy Journal 2016, 37, 3, p. 471-472; M. Schmid-Drüner, The situation..., p. 1; A. Aloisi, Commoditized..., p. 660-661. More about crowdsourcing, see: A. Donini, Mercato del lavoro sul web: regole e opportunità, Diritto delle Relazioni Industriali 2015, 2, p. 450-454.

7 J. Webster, K. Randle, Positioning virtual workers within space, time, and social dynamics, in: Virtual Workers and the Global Labour Market, J. Webster, K. Randle (eds.), London 2016, p. 9-10. See also: A. Aloisi, Commoditized..., p. 666; V. De Stefano, The Rise..., p. 474; J. Berg, Income security in the on-demand economy: Findings and policy lessons from a survey of crowdworkers, Comparative Labor Law \& Policy Journal 2016, 37, 3, p. 545-546.

8 A. Donini, Il lavoro su piattaforma digitale "prende forma" tra autonomia e subordinazione. Nuove regole per nuovi lavori?, Diritto delle Relazioni Industriali 2016, 1, p. 166; J. Prassl, M. Risak, Uber, taskrabbit, and Co.: Platforms as employers? Rethinking the legal analysis of crowdwork, Comparative Labor Law \& Policy Journal 2016, 37, 3, p. 623-624; B. Gomes, Le crowdworking..., p. 467.

9 V. De Stefano, The Rise..., p. 471 and 473.

10 A. Aloisi, Commoditized..., p. 654.

11 See J. Prassl, M. Risak, Uber..., p. 620 and 627. 


\section{Why protection is of the essence?}

It goes without saying that the global economy has rendered virtual workers a "cybertariat", that is "an increasingly precarious «cyberproletariat» composed of diverse waged and unwaged labourers in digital networks". ${ }^{12}$ Regardless of the kind of work being performed, working conditions for the considerable majority of crowdworkers are poor. They are even called "digital slaves" due to a lack of regulation, a lack of union representation and organizing power, the oligopoly of platforms, and constant economic and legal insecurity resulting in a significant imbalance of bargaining power. ${ }^{13}$ The immense majority of people accept this type of job because they are unable to find a better one. ${ }^{14}$ Earning money is the primary motivation for workers to crowd work, even for very low paid tasks. The flexibility and a better work-life-balance take the second place. ${ }^{15}$ However, not infrequently minimum wages are out of reach for those labelled as independent contractors, even if many indicators reveal a disguised employment relationship. A high proportion of risk is transferred to workers, so that the employer can avoid potential costs, e.g. unemployment insurance,$^{16}$ overtime compensation, family and medical leave, employer payroll taxes. ${ }^{17}$ In this way technological platforms contribute to the growing precariousness of work. ${ }^{18}$ Moreover, it is often unsure even from hour to hour whether there will be work to do, and how much it will pay. The insecure employment and income are connected with psychological morbidity. In the literature these workers are called "workers provided «just-in-time» and compensated on a "pay-as-you-go» basis". ${ }^{19}$ Additionally, precarious workers can be trapped in a situation where they need a second job to survive, but having an extra job means that the scheduling may get a worker fired from the first one. ${ }^{20}$

Another problematic issue is linked to reputational feedback mechanisms - tools used to control, e.g. the Uber drivers by relying on feedback from customers about their performance. By means of technology employers are able to maintain and strengthen this control. The corporation uses the ratings and other information collected in order

12 J. Webster, K. Randle, Positioning..., p. 22; see the cited literature.

13 J. Prassl, M. Risak, Uber..., p. 626; see the cited literature.

14 R. Gutiérrez Arranz, Las relaciones laborales en la economia colaborativa: el caso Uber en EE.UU., Nueva Revista Española de Derecho del Trabajo 2016, 187, p. 166.

15 M. Schmid-Drüner, The situation..., p. 3. Platforms often constitute a crucial source of income for workers, and even the main living. A. Aloisi, Commoditized..., p. 658.

16 A. Aloisi, Commoditized..., p. 653.

17 S.A. Donovan, D.H. Bradley, J.O. Shimabukuro, What does the gig economy mean for workers?, Congressional Research Service: Report 2016, p. 11.

18 J. Drahokoupil, B. Fabo, The platform economy and the disruption of the employment relationship, European Trade Union Institute Policy Brief, European Economic, Employment and Social Policy 2016, 5, p. 4 .

19 M. Schmid-Drüner, The situation..., p. 15; see the cited literature.

20 M. A. Cherry, Beyond..., p. 598; see the cited literature. 
to monitor drivers' actions and ensure that they comply with Uber policy. This is what creates subordination. ${ }^{21}$

In other words, Uber has outsourced its quality control to passengers. After the ride passengers are asked to rate a driver on a scale of one to five, with five stars as the best score. Then, the ratings are averaged with the purpose of providing a composite score. If a rating falls below an approximate threshold of 4,7 out of five stars, the driver can no longer sign in to the app. His/her account is simply deactivated. Another problem is that these ratings often appear to involve racial or religious bias. In fact, problems of discrimination reflected in ratings are seemingly endless. ${ }^{22}$

\section{What is the status of on-demand workers?}

On-demand businesses claim they are only technology companies that link individuals with third party services. ${ }^{23}$ Thus, as it has been already stated, labour law protection is often out of reach for those classified as independent contractors, even if many indicators reveal a disguised employment relationship. For that reason, scientists try to address current misclassification issues in different ways. As indicated by M.A. Cherry and A. Aloisi, currently, if a corporation treats workers as independent contractors, it is left up to the workers to prove otherwise. According to these authors, the default presumption should be changed. The default classification would be an employment relationship on the assumption that a worker has worked a minimum threshold of hours. Such a situation would come into play even if the work was performed on a platform or exclusively in cyberspace. The relationship would be treated as an employment relationship even if the worker provided his/her own tools, even if the arrangement were flexible, and even if it was considered part-time employment. However, for those who are truly independent and genuinely self-employed, there would be opt-outs. ${ }^{24}$ The above concept was developed against a background of criticism of proposals to introduce a third category. ${ }^{25}$ The authors

21 G. Davidov, The Status of Uber Drivers: A Purposive Approach; http://www.labourlawresearch.net/ sites/default/files/papers/The\%20status\%20of\%20Uber\%20drivers\%20A\%20purposive\%20approach\%20 copy.pdf (accessed: 14.09.2017).

22 E. Dagnino, Uber law: prospettive giuslavoristiche sulla sharing/on-demand economy, Diritto delle Relazioni Industriali 2016, 1, p. 152-153; M.A. Cherry, Beyond..., p. 597. See also D. Das Acevedo, Regulating employment relationships in the sharing economy, Employee Rights \& Employment Policy Journal 2016, 20, 1, p. 20.

23 A.L. Crank, O'Connor v. Uber technologies, Inc.: The dispute lingers - are workers in the on-demand economy employees or independent contractors?, American Journal of Trial Advocacy 2016, 39, 3, p. 610; B. Rogers, Employment rights in the platform economy: Getting back to basics, Harvard Law \& Policy Review 2016, 10, 2, p. 480.

24 M.A. Cherry, A. Aloisi, "Dependent contractors" in the gig economy: A comparative approach, American University Law Review 2017, 66, 3, p. 682-683.

25 The adoption of a "dependent contractor" as a third employment classification has been proposed, e.g. by E.E. McCabe. See: E.E. McCabe, Not like the others..., p. 165-171. 
pointed out that the intermediate category between employee and independent contractor is nothing new. Some foreign legal systems have already had experience with implementing a hybrid category. However, M.A. Cherry and A. Aloisi warn that experimenting with a third category might be risky. Its adoption in Italy resulted in "widespread arbitrage of the categories with businesses moving employees into a «bogus» discounted status in the quasi-subordinate category". In Spain, the third category is applicable only to a small part of workers because of the fact that the requirements for joining the hybrid category were burdensome. ${ }^{26}$

Shifting in focus from notions of the employee to the concept of the employer, according to J. Prassl and M. Risak, on grounds of a functional concept of the employer, e.g. Uber should be identified as such. The five main functions of the employer and their functional foundations are:

1. Commencement and termination of the employment relationship: this function encompasses all powers of the employer over the existence of a relationship with the employee.

2. Receiving labour and collecting its fruits: duties owed by the employee to the employer, especially providing labour and the results thereof.

3. Providing work and pay: the employer's obligations toward employees, inter alia a payment of remuneration.

4. Managing the enterprise - internal market: coordination through control exerted over all factors of production, inclusive of setting requirements of both how and what should be done.

5. Managing the enterprise - external market: not only undertaking economic activity in return for potential profit, but also being exposed to any losses that may result from running the business.

All conditions must be met by the platform to be considered as the employer. In fact, the corporation exerts a full control over the existence of the relationship, it is in charge of starting and terminating a driver's access to the platform. Moreover, Uber is the direct recipient of the fruits of labour carried out by the driver: payment is taken automatically from the passenger's credit card. As regards the provision of work and pay, a smartphone which allows drivers access to its network of customers should be considered as a crucial instrument. When it comes to managing the enterprise, Uber controls, to a considerable extent, all aspects of how a ride is provided, from using reputational feedback mechanisms to deciding about the music to be played during the ride. Finally, Uber is the company undertaking economic activity in return for potential profit, and is exposed to any losses that may result from running the business. The crucial indicator of driver's earning ability is Uber's dynamic pricing algorithm determining money for distance and time on the grounds of factors such as individual city pricing levels, or even demand specific to a particular location and time though so-called surge pricing. Besides, the corporation has full control over branding, thereby is able to provide

26 M.A. Cherry, A. Aloisi, “Dependent contractors”..., p. 637 and 688. 
a global service under a unified mantle. As follows from this analysis, Uber should be treated as an employer and should be responsible for ensuring employment rights in each jurisdiction it operates. ${ }^{27}$

Let's now turn our attention to the judgment of Employment Tribunal in Aslam and Farrar and others v Uber BV, Uber London Ltd and Uber Britannia Ltd (2202550/2015) of 2016, October. According to the judgment, Uber is the employing entity. An interesting argumentation has been presented on why it is difficult to classify Uber drivers as self-employed persons.

First of all, Uber recruits, controls, instructs, disciplines and dismisses drivers. The company determines disputes affecting their interests. Moreover, as it has been highlighted in the judgment, a certain degree of scepticism should be retained if an organisation: (1) runs an enterprise fulfilling the function of carrying people in motor cars from where they are to where they want to be and (2) operates in part through a company discharging the regulated responsibilities of a PHV operator, but (3) requires drivers and passengers to agree, as a matter of contract, that it does not provide transportation services, and (4) resorts in its documentation to fictions, twisted language and even brand new terminology. In this context, the problem is also related to the unequal bargaining positions of the contracting parties (many Uber drivers will not be used to read and interpret dense legal documents). It has been also stated that the drivers are under no obligation to switch on the App indeed. However, the driver who has the App switched on, is within the territory in which he/she is authorised to work, and is able and willing to accept passenger transport, is working for Uber under a "worker" contract. Furthermore, an individual driver does not offer a variety of driving services. Obviously, the marketing is not done for the benefit of any solo driver. By contrast, it is done to promote Uber's name and sell its transportation services. An individual drivers cannot grow his/her business, cannot negotiate with passengers. He/she is offered and accepts tasks exclusively on Uber's terms. The company cannot be regarded as a mosaic of 30,000 small businesses linked by a common platform. It has been also pointed out that no contract for the provision of transportation services exists between the driver and Uber. Instead, the driver is required to agree that a contract for such services exists between him and the passenger. It turns out that when the driver enters into a binding agreement with a passenger, they do not know and will never know each other's identity. The driver should undertake a trip to a destination which is not familiar to him/her until the journey begins. He/she should travel a route prescribed by Uber (a stranger to the contract) from which he/she is not free to depart, for a fee which: (1) is set by the stranger to the contract, (2) is not known by the passenger (who is only told the total to be paid), (3) is calculated by the stranger (as a percentage of the total sum) and (4) is paid to the stranger. Uber's intention is that if the organisation became insolvent, the drivers would have enforceable rights directly against the passengers. It has been held that the supposed contract between a driver and a passenger is a pure fiction which

$27 \quad$ J. Prassl, M. Risak, Uber..., p. 636-641. 
bears no relation to the real dealings and relationships between them. In actual fact, Uber runs a business, delivers its transportation services through the driver's skilled labour and earns profits.

In light of Aslam and Farrar and others case, Uber drivers cannot be classified as self-employed persons also for further reasons.

1. The inconsistency resulting from Uber's Terms, between the fact that the company claims to be the drivers' agent and, on the other hand, its assertion of "sole and absolute discretion" to accept and decline bookings.

2. The fact that Uber interviews and recruits drivers.

3. The fact that the company (and not the driver) exercises control over the crucial information, e.g. the passenger's surname, contact details or intended destination.

4. The fact that Uber requires drivers to accept and not to cancel trips, and enforces the requirement by deactivating drivers who do not comply with those requirements.

5. The fact that the company sets the default route and the driver departs from it at his/her own risk.

6. The fact that Uber fixes the fare and the driver can do nothing to agree a higher or lower sum with the passenger.

7. The fact that Uber imposes several conditions on drivers, e.g. there is a limited choice of acceptable vehicles.

8. The fact that Uber instructs drivers as to how to perform their work and controls them in the execution of their tasks.

9. The fact that Uber employs reputational feedback mechanisms is equivalent to management or disciplinary procedure.

10. The fact that Uber offers rebates without involving the driver whose remuneration is liable to be affected.

11. The fact that the risk of loss is accepted by Uber, and if the drivers were genuinely self-employed, it would fall upon them.

12. The fact that Uber deals with complaints submitted by passengers, also including those about the drivers.

13. The fact that Uber retains the right to amend the drivers' terms unilaterally.

14. The fact that the work is obviously conducted personally.

In consequence, it has been stated that since there is no contract with the passenger, the finding of a contractual link with Uber is unavoidable. The drivers are recruited and retained by Uber in order to enable it to run its business and to work as integral components of its organisation. An indispensable bargain between driver and company is that the driver, for remuneration, makes himself/herself available to carry Uber passengers to their destinations. If there is a contract with Uber, it is obviously not a contract under which Uber is a client or customer of a business operated by the driver. The agreement between the parties is not a contract between two independent business undertakings. It is rather to be located in the field of dependent work relationships. 
In trying to determine the status of on-demand workers one could concentrate his/her attention on the European agenda for the collaborative economy. ${ }^{28}$ In this document the European Commission makes reference to the definition of "worker" in EU law. Taking into consideration cumulatively especially three indispensable criteria - the existence of a subordination link, the nature of work, and the presence of a remuneration - it is to be established whether an employment relationship exists or not. What is important, it may also apply to platform workers. According to the agenda, many of the common arguments put forward by the platforms, such as that the work does not take place continuously, and that workers are not constantly monitored, are not sufficient to avoid qualification of platform work as a working relationship. ${ }^{29}$

\section{The right to informational self-determination and the broad concept of "personal data"}

Problems of data protection in the digital era are increasingly highlighted in the literature. ${ }^{30}$ My aim in this article is to reflect on this issue from the perspective of the General Data Protection Regulation. ${ }^{31}$ According to its article 4 (1) "personal data" means any information relating to an identified or identifiable natural person ("data subject"); an identifiable natural person is one who can be identified, directly or indirectly, in particular by reference to an identifier such as a name, an identification number, location data, an online identifier or to one or more factors specific to the physical, physiological, genetic, mental, economic, cultural or social identity of that natural person.

There is no doubt that the objective information about the number of tasks that have not been fulfilled by the employee is a personal data. ${ }^{32}$ For example, if an Uber driver rejects transporting a minor, he or she risks receiving negative feedback, reflected in the

${ }^{28}$ Communication from the Commission to the European Parliament, the Council, the European Economic and Social Committee and the Committee of the Regions. A European agenda for the collaborative economy, Brussels 2016, p. 12-13.

${ }^{29}$ See M. Hernández Bejarano, El apoyo europeo al modelo de economía colaborativa: algunas cuestiones y propuestas para afrontar una regulación laboral y de seguridad social, Nueva Revista Española de Derecho del Trabajo 2016, 192, p. 173-174.

${ }^{30}$ See e.g. M. Weiss, Digitalizzazione: sfide e prospettive per il diritto del lavoro, Diritto delle Relazioni Industriali 2016, 3, p. 658-659; F. Seghezzi, Lavoro e relazioni industriali nell'Industry 4.0., Diritto delle Relazioni Industriali 2016, 1, p. 202, see the cited literature.

${ }^{31}$ Regulation (EU) 2016/679 of the European Parliament and of the Council of 27 April 2016 on the protection of natural persons with regard to the processing of personal data and on the free movement of such data, and repealing Directive 95/46/EC (General Data Protection Regulation), Official Journal of the European Union, 2016, L 119/1; http://eur-lex.europa.eu/legal-content/EN/TXT/HTML/?uri=C ELEX:32016R0679\&from=PL (accessed: 14.09.2017).

32 M. Krzysztofek, Ochrona danych osobowych w Unii Europejskiej po reformie. Komentarz do rozporządzenia Parlamentu Europejskiego i Rady (UE) 2016/679, Legalis 2016. 
rating, even if it is illegal to accept unaccompanied minors. ${ }^{33}$ In this case, an information objectively untrue or unfair (appearing in undervaluation), but referring to the fact (rejection of transporting) constitutes a personal data as well. ${ }^{34}$ Drivers should have the possibility to have their ratings removed.

Historically, in 1983 the German Constitutional Court recognized "the right to informational self-determination". Basing on the human dignity and personality right, the Court stated that the "basic right warrants (...) the capacity of the individual to determine in principle the disclosure and use of his/her personal data". ${ }^{35}$ According to the Court, the right to informational self-determination facilitates the free development of the individual's personality, encompasses the interaction with the other members of the society on an equal basis and allows the individual to participate in a democratic society in a free way and without the fear of being prosecuted. Due to the recognition of the right to informational self-determination by the German Constitutional Court, the concept of consent increased in importance. It implied an enhanced participation of the citizens in the processing of their personal information. ${ }^{36}$

The General Data Protection Regulation establishes a data subject's right to have personal data concerning him or her rectified and a "right to be forgotten" where the retention of such data infringes the Regulation or Union or Member State law to which the controller is subject. In motif 65 the Regulation further states that in particular, a data subject should have the right to have his or her personal data erased and no longer processed where the personal data are no longer necessary in relation to the purposes for which they are collected or otherwise processed, where a data subject has withdrawn his or her consent or objects to the processing of personal data concerning him or her, or where the processing of his or her personal data does not otherwise comply with the Regulation. Article 17 of the General Data Protection Regulation concretizes the right to erasure ("right to be forgotten"). It states that:

1. The data subject shall have the right to obtain from the controller the erasure of personal data concerning him or her without undue delay and the controller shall have the obligation to erase personal data without undue delay where one of the following grounds applies:

(a) the personal data are no longer necessary in relation to the purposes for which they were collected or otherwise processed;

(b) the data subject withdraws consent on which the processing is based according to the Articles mentioned in the Regulation, and where there is no other legal ground for the processing;

33 M. Schmid-Drüner, The situation..., p. 13.

34 M. Krzysztofek, Ochrona...

35 A. Rouvroy, Y. Poullet, The right to informational self-determination and the value of self-development: Reassessing the importance of privacy for democracy, in: S. Gutwirth, Y. Poullet, P. De Hert, C. De Terwangne, S. Nouwt (eds.), Reinventing Data Protection?, Dordrecht 2009, p. 45.

36 B. Van Alsenoy, E. Kosta, J. Dumortier, Privacy notices versus informational self-determination: Minding the gap, International Review of Law, Computers \& Technology 2014, 28, 2, p. 188. 
(c) the data subject objects to the processing exercising right to object deriving from Article 21(1) and there are no overriding legitimate grounds for the processing, or the data subject objects to the processing pursuant to Article 21(2);

(d) the personal data have been unlawfully processed;

(e) the personal data have to be erased for compliance with a legal obligation in Union or Member State law to which the controller is subject;

(f) the personal data have been collected in relation to the offer of information society services referred to in Article 8(1) (the offer of information society services directly to a child).

2. Where the controller has made the personal data public and is obliged pursuant to paragraph 1 to erase the personal data, the controller, taking account of available technology and the cost of implementation, shall take reasonable steps, including technical measures, to inform controllers which are processing the personal data that the data subject has requested the erasure by such controllers of any links to, or copy or replication of, those personal data.

Article 17 paragraph 3 establishes exceptions, that is circumstances under which processing is necessary so paragraphs 1 and 2 shall not apply.

\section{Profiling}

Profiling increasingly present nowadays, consists of determining the profile of people on the basis of statistical data in order to determine the expected behavior, and may give rise to a number of dangers, including invasion of privacy and discrimination. Provisions of the General Data Protection Regulation establish the protection against the abuse of profiling. According to article 4 (4) of the General Data Protection Regulation, "profiling" means any form of automated processing of personal data consisting of the use of personal data to evaluate certain personal aspects relating to a natural person, in particular to analyse or predict aspects concerning that natural person's performance at work, economic situation, health, personal preferences, interests, reliability, behaviour, location or movements. In accordance with this definition, two cumulative conditions should be met for the qualification of a particular form of processing of personal data as profiling. First, we have to deal with an automated form of processing of personal data, and secondly, it must rely on the assessment of human factors on the basis of personal data processed. The first premise should be understood as such a form of processing of personal data which occurs without human intervention. It can be inferred from the motif 71 of the General Data Protection Regulation which deals with the automatic refusal of an online credit application or e-recruiting practices without any human intervention. The second condition assumes that not any automated processing of personal data, but only the one that results in making the assessment of human factors, can be treated as 
profiling. ${ }^{37}$ It appears that the issues problematised above are in line with mechanisms adopted by the on-demand economy. In regard to the first condition, e.g. Lyft may automatically terminate the agreement or deactivate the User account immediately in the event the driver falls below Lyft's star rating or cancellation threshold. ${ }^{38}$ Moreover, what refers to the second premise, the General Data Protection Regulation itself mentions in the article 4 (4) e.g. natural person's performance at work. This finding leads us to conduct further analysis of profiling.

Article 22 (1) of the General Data Protection Regulation states that the data subject shall have the right not to be subject to a decision based solely on automated processing, including profiling, which produces legal effects concerning him or her or similarly significantly affects him or her. We can infer from the word "solely" that if a man is involved in the decision-making process, profiling will not be banned. In turn, producing legal effects concerning the data subject means the creation, modification or termination of the legal relationship. However, interpretative doubts arise with regard to the profiling which similarly significantly affects him or her. Some authors indicate that these are situations in which the decision affects the sphere of rights and duties of the individual, but in a different way than the creation, modification or termination of the legal relationship, e.g. by refusing to conclude an agreement with him or her ${ }^{39}$. If the above conditions are satisfied, the decision concerning the data subject generally cannot be based solely on profiling.

There are three exceptions from the above-mentioned rule. The data subject do not have the right established in article 22 (1) if the decision:

(a) is necessary for entering into, or performance of, a contract between the data subject and a data controller;

(b) is authorised by Union or Member State law to which the controller is subject and which also lays down suitable measures to safeguard the data subject's rights and freedoms and legitimate interests; or

(c) is based on the data subject's explicit consent.

In the cases referred to in points (a) and (c), the data controller shall implement suitable measures to safeguard the data subject's rights and freedoms and legitimate interests, at least the right to obtain human intervention on the part of the controller, to express his or her point of view and to contest the decision.

The existence of profiling figures among the supplementary information necessary to ensure fair and transparent processing..$^{40}$ According to article 13 (2) point (f), the

37 W. Chomiczewski, Profilowanie w ogólnym rozporządzeniu o ochronie danych, in: E. Bielak-Jomaa, D. Lubasz (eds.), Polska i europejska reforma ochrony danych osobowych, LEX 2016.

38 Https://www.lyft.com/terms; http://www.ridesharingservices.com/2014/10/the-steps-to-lyftdeactivation-real.html (accessed: 14.09.2017).

39 W. Chomiczewski, Profilowanie...

40 I. Gheorghe-Badescu, Le nouveau règlement général sur la protection des données. Quoi de neuf?, Revue de l'Union Européenne 2016, 9, 601, p. 474. Moreover, according to the motif 71 of the General Data Protection Regulation: "In order to ensure fair and transparent processing in respect of the data subject, 
controller shall, at the time when personal data are obtained, provide the data subject with further information, among others with the existence of automated decision-making, including profiling and, at least in those cases, meaningful information about the logic involved, as well as the significance and the envisaged consequences of such processing for the data subject.

The General Data Protection Regulation introduces the right of the data subject to object, on grounds relating to his or her particular situation, at any time to profiling based on point (e) or (f) of article 6 (1). It comes to cases of lawfulness of processing justified by the following prerequisites:

(e) processing is necessary for the performance of a task carried out in the public interest or in the exercise of official authority vested in the controller;

(f) processing is necessary for the purposes of the legitimate interests pursued by the controller or by a third party, except where such interests are overridden by the interests or fundamental rights and freedoms of the data subject which require protection of personal data, in particular where the data subject is a child. This does not apply to processing carried out by public authorities in the performance of their tasks. Moreover, where personal data are processed for direct marketing purposes, the data subject shall have the right to object at any time to processing of personal data concerning him or her for such marketing, which includes profiling to the extent that it is related to such direct marketing. Where the data subject objects to processing for direct marketing purposes, the personal data shall no longer be processed for such purposes.

\section{Conclusion}

The role of gig workers in the economy is growing. In certain cases, technological platforms can contribute to the precariousness of work. As it has been demonstrated, the majority of people accept this type of work because they are unable to find a better one. The aim of employment and labour law should be to distinguish the genuinely self-employed from those who remain in a disguised employment relationship. For that reason, it would be reasonable to take action to introduce labour and employment laws into the 21st century and ensure the protection of the latter category. Moreover, problems of data protection of the on-demand workers are highlighted in the literature.

taking into account the specific circumstances and context in which the personal data are processed, the controller should use appropriate mathematical or statistical procedures for the profiling, implement technical and organisational measures appropriate to ensure, in particular, that factors which result in inaccuracies in personal data are corrected and the risk of errors is minimised, secure personal data in a manner that takes account of the potential risks involved for the interests and rights of the data subject and that prevents, inter alia, discriminatory effects on natural persons on the basis of racial or ethnic origin, political opinion, religion or beliefs, trade union membership, genetic or health status or sexual orientation, or that result in measures having such an effect. Automated decision-making and profiling based on special categories of personal data should be allowed only under specific conditions." 
Therefore, it is worth using some of the protective instruments provided by the General Data Protection Regulation.

\section{References}

Aloisi A., Commoditized workers: Case study research on labor law issues arising from a set of “on-demand/gig economy" platforms, Comparative Labor Law \& Policy Journal 2016, 37, 3.

Berg J., Income security in the on-demand economy: Findings and policy lessons from a survey of crowdworkers, Comparative Labor Law \& Policy Journal 2016, 37, 3.

Cherry M.A., Aloisi A., "Dependent contractors" in the gig economy: A comparative approach, American University Law Review 2017, 66, 3.

Cherry M.A., Beyond misclassification: the digital transformation of work, Comparative Labor Law \& Policy Journal 2016, 37, 3.

Chomiczewski W., Profilowanie $w$ ogólnym rozporządzeniu o ochronie danych, in: E. Bielak-Jomaa, D. Lubasz (eds.), Polska i europejska reforma ochrony danych osobowych, LEX 2016.

Communication from the Commission to the European Parliament, the Council, the European Economic and Social Committee and the Committee of the Regions. A European agenda for the collaborative economy, Brussels 2016.

Crank A.L., O'Connor v. Uber technologies, Inc.: The dispute lingers - are workers in the on-demand economy employees or independent contractors?, American Journal of Trial Advocacy 2016, $39,3$.

Dagnino E., Uber law: prospettive giuslavoristiche sulla sharing/on-demand economy, Diritto delle Relazioni Industriali 2016, 1.

Das Acevedo D., Regulating employment relationships in the sharing economy, Employee Rights \& Employment Policy Journal 2016, 20, 1.

Däubler W., Klebe T., Crowdwork: datore di lavoro in fuga?, Giornale di diritto del lavoro e di relazioni industriali fondato da Gino Giugni, 2016, 131, 3.

Davidov G., The Status of Uber Drivers: A Purposive Approach; http://www.labourlawresearch.net/ sites/default/files/papers/The\%20status\%20of\%20Uber\%20drivers\%20A\%20purposive $\% 20$ approach\%20copy.pdf (accessed: 14.09.2017).

De Stefano V., The rise of the "just-in-time workforce": On-demand work, crowdwork, and labor protection in the "gig economy", Comparative Labor Law \& Policy Journal 2016, 37, 3.

Donini A., Il lavoro su piattaforma digitale "prende forma" tra autonomia e subordinazione. Nuove regole per nuovi lavori?, Diritto delle Relazioni Industriali 2016, 1.

Donini A., Mercato del lavoro sul web: regole e opportunità, Diritto delle Relazioni Industriali 2015, 2.

Donovan S.A., Bradley D.H., Shimabukuro J.O., What does the gig economy mean for workers?, Congressional Research Service: Report 2016.

Drahokoupil J., Fabo B., The platform economy and the disruption of the employment relationship, European Trade Union Institute Policy Brief, European Economic, Employment and Social Policy 2016, 5. 
Gheorghe-Badescu I., Le nouveau règlement général sur la protection des données. Quoi de neuf?, Revue de l'Union Européenne 2016.

Gomes B., Le crowdworking: essai sur la qualification du travail par intermédiation numérique, Revue de Droit du Travail 2016, 7-8.

Gutiérrez Arranz R., Las relaciones laborales en la economia colaborativa: el caso Uber en EE.UU., Nueva Revista Española de Derecho del Trabajo 2016, 187.

Hernández Bejarano M., El apoyo europeo al modelo de economía colaborativa: algunas cuestiones y propuestas para afrontar una regulación laboral y de seguridad social, Nueva Revista Española de Derecho del Trabajo 2016, 192.

Krzysztofek M., Ochrona danych osobowych w Unii Europejskiej po reformie. Komentarz do rozporządzenia Parlamentu Europejskiego i Rady (UE) 2016/679, Legalis 2016.

Manyika J., Lund S., Robinson K., Valentino J., Dobbs R., A labor market that works: connecting talent with opportunity in the digital age, 2015; http://www.mckinsey.com/global-themes/ employment-and-growth/connecting-talent-with-opportunity-in-the-digital-age (accessed: 14.09.2017).

McCabe E.E., Not like the others: Applying the fair labor standards act to the sharing economy, Kansas Law Review 2016, 65, 1.

Prassl J., Risak J., Uber, taskrabbit, and Co.: Platforms as employers? Rethinking the legal analysis of crowdwork, Comparative Labor Law \& Policy Journal 2016, 37, 3.

Regulation (EU) 2016/679 of the European Parliament and of the Council of 27 April 2016 on the protection of natural persons with regard to the processing of personal data and on the free movement of such data, and repealing Directive 95/46/EC (General Data Protection Regulation), Official Journal of the European Union, 2016, L 119/1; http://eur-lex.europa.eu/ legal-content/EN/TXT/HTML/?uri=CELEX:32016R0679\&from=PL (accessed: 14.09.2017).

Rogers B., Employment rights in the platform economy: Getting back to basics, Harvard Law \& Policy Review 2016, 10, 2.

Rouvroy A., Poullet Y., The right to informational self-determination and the value of self-development: Reassessing the importance of privacy for democracy, in: S. Gutwirth, Y. Poullet, P. De Hert, C. De Terwangne, S. Nouwt (eds.), Reinventing Data Protection?, Dordrecht 2009.

Sanders D.E., Pattison P., Worker characterization in a gig economy viewed through an Uber centric lens, Southern Law Journal 2016, 26, 2.

Schmid-Drüner M., The situation of workers in the collaborative economy, European Parliament 2016.

Seghezzi F., Lavoro e relazioni industriali nell'Industry 4.0., Diritto delle Relazioni Industriali 2016, 1

Van Alsenoy B., Kosta B., Dumortier J., Privacy notices versus informational self-determination: Minding the gap, International Review of Law, Computers \& Technology 2014, 28, 2.

Webster J., Randle K., Positioning virtual workers within space, time, and social dynamics, in: Virtual Workers and the Global Labour Market, J. Webster, K. Randle (eds.), London 2016.

Weiss M., Digitalizzazione: sfide e prospettive per il diritto del lavoro, Diritto delle Relazioni Industriali 2016, 3. 